\title{
PSYCHOLOGY
}

\section{ОСОБЛИВОСТІ ЗМІНИ СТРУКТУРНИХ КОМПОНЕНТІВ «Я-ОБРАЗУ» ОСОБИСТОСТІ В СКЛАДНИХ ЖИТТЕВИХ ОБСТАВИНАХ}

\author{
Доктор психологічних наук, професор кафедри соціальної роботи Швалб Ю. М., Україна, \\ м. Київ, Київський начіональний університет ім. Т. Г. Шевченко; \\ здобувач, Інститут психології імені Г.С. Костюка НАПН Украӥни Кулікова А. О., м. Київ, \\ старший викладач кафедри практичної психології, Маріупольський державний університет
}

DOI: https://doi.org/10.31435/rsglobal_wos/31052019/6503

\section{ARTICLE INFO}

Received: 28 March 2019

Accepted: 17 May 2019

Published: 31 May 2019

\section{KEYWORDS}

components, «Self-image», personality, complicated life circumstances, divorce, temporary disability, temporary displaced people, unemployed. \begin{abstract}
This article presents the influence of complex life circumstances on the structural components of the «Self-image» of the individual. The circumstances in which the person appears are devastating, namely, they can transform (change) the «Self-image». This phenomenon has the basic structural components: cognitive, emotional, evaluative and behavioral. And these components vary in different ways depending on the type of complex life circumstances. In this article the authors compare the changes in these components among the divorced people, people with temporary disabilities (broken hand or leg, 9-12 months of rehabilitation), the unemployed (fired from the enterprise in connection with its reorganization) and people temporary displaced from Donetsk area. On the basis of the obtained data, it is possible to construct various forms and types of psychological work with people who have fallen into difficult living conditions.
\end{abstract}

Citation: Швалб Ю. М., Кулікова А. О. (2019) Osoblyvosti Zminy Strukturnykh Komponentiv «YaObrazu» Osobystosti v Skladnykh Zhyttievykh Obstavynakh. International Academy Journal Web of Scholar. 5(35). doi: 10.31435/rsglobal_wos/31052019/6503

Copyright: (C) 2019 Швалб Ю. М., Кулікова А. О. This is an open-access article distributed under the terms of the Creative Commons Attribution License (CC BY). The use, distribution or reproduction in other forums is permitted, provided the original author(s) or licensor are credited and that the original publication in this journal is cited, in accordance with accepted academic practice. No use, distribution or reproduction is permitted which does not comply with these terms.

Вступ. Питання існування особистості у складних життєвих обставинах є надзвичайно актуальним у нашому суспільстві в останні роки у зв'язку із значними змінами у соціальному, економічному та політичному просторі життєдіяльності людини. Складні життєві обставини є однією з форм життєвої кризи особистості, яка охоплює ії внутрішнє «Я». У науковій літературі поняття «Я-образ» з'явилося у зв'язку з необхідністю дослідження і опису глибинних психологічних структур і процесів особистості. «Я-образ» - це набір ідей, уявлень, установок і почуттів людини про себе, про свої взаємозв'язки з іншими людьми, про своє ставлення до різних аспектів життя [1]. I тому переживання складних життєвих обставин нерідко супроводжується різного роду психологічними проблемами пов'язаними з прийняттям себе, з розбіжністю між бажаним і дійсним, 3 використанням неефективних стратегій поведінки, руйнуванням або трансформацією «Я-образу» тощо. «Я-образ» має певні структурні компоненти: когнітивний, як сукупність уявлень про себе, про свої якості, здібності, зовнішність, тощо; емоційно-ціннісний - афективна оцінка уявлень про себе, а саме самоповага, себелюбність, самоприниження; поведінковий - потенційна поведінкова реакція, тобто ті конкретні дії, які можуть викликатися «Я-образом» і самооцінкою [2]. Отже, якщо «Я-образ» змінюється під впливом життєвих ситуацій та обставин, необхідно визначити саме феноменологію поняття «обставини». Поняття «обставини» фіксує те, що знаходиться за межами психічних функцій індивіда, але впливає на його поведінку або діяльність. Складні життєві обставини - це обставини, спричинені інвалідністю, віком, станом здоров'я, соціальним 
становищем, розлученням, життєвими звичками і способом життя, внаслідок яких особа частково або повністю не має (не набула або втратила) здатності чи можливості самостійно піклуватися про особисте (сімейне) життя та брати участь у суспільному житті. Саме воно стало підставою для формування вибірки дослідження [3].

Результати дослідження. У дослідженні приймали участь:

1. розлучені з різним періодом. Розлучення - припинення шлюбу за життя подружжя за заявою одного або двох із подружжя; 2. особи, які мають тимчасову інвалідність (перелом руки або ноги, 9-12 міс. реабілітаціі). Тимчасова непрацездатність (інвалідність) - це непрацездатність особи внаслідок захворювання, травми або 3 інших причин, що не залежить від факту втрати працездатності; 3. безробітні особи (звільнені у зв'язку із скороченням в організації або підприємств). Безробітні - працездатні громадяни працездатного віку, які з незалежних від них причин не мають заробітку або інших передбачених чинним законодавством доходів через відсутність підходящої роботи; 4. переселенці з Донецької області. Переселенець - це той, хто переселився, переселяється на нове місце проживання або переселений куди-небудь [4].

Програма емпіричного дослідження включала IV етапи.

Перший етап присвячений визначенню змін, яких потерпають структурні компоненти «Я-образу» під впливом складної життєвої обставини - розлучення. Результати показників за даним етапом представлені у таблиці 1.

Таблиця 1. Результати дослідження за тестом - опитувальником самовідношення В.В. Століна, С.Р. Пантілєєва у \%.

\begin{tabular}{|c|c|c|c|c|c|c|c|c|c|c|}
\hline \multirow{2}{*}{$\begin{array}{c}\text { №, групи } \\
\text { досліджуваних }\end{array}$} & \multirow[b]{2}{*}{ 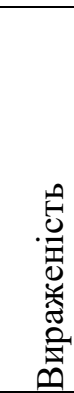 } & \multicolumn{9}{|c|}{ Показники у \% } \\
\hline & & 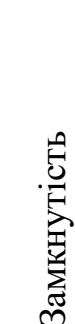 & 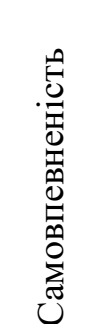 & 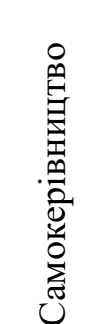 & 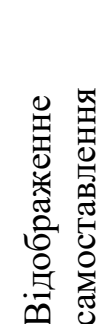 & 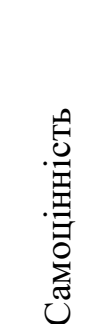 & 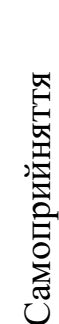 & 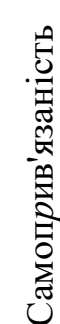 & 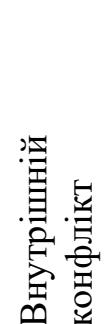 & 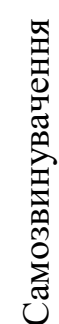 \\
\hline \multirow[t]{3}{*}{ 1. Розлученні } & вис. & 87,5 & 10 & 7,5 & 5 & 2,5 & 15 & 80 & 92,5 & 10 \\
\hline & cep. & 5 & 72,5 & 75 & 17,5 & 20 & 5 & 0 & 2,5 & 47 \\
\hline & низ. & 7,5 & 17,5 & 17,5 & 77,5 & 77,5 & 80 & 20 & 5 & 43 \\
\hline
\end{tabular}

За даними нашого дослідження у розлучених високі показники за шкалами: «замкнутість» (87,5\%), «самоприв'язаності» (80\%) та «внутрішній конфлікт» (92,5\%). За низькими показниками: «самоприйняття» $(80 \%)$ та «відображене самоставлення» $(77,5 \%)$. Усі інші шкали мають середній рівень вираженості показників. що свідчить про виражену захисну поведінку особистості. Ці показники свідчать про бажання відповідати загальноприйнятим нормам поведінки і взаємин 3 оточуючими людьми, відображають високу ригідність «Я», прагнення зберегти в незмінному вигляді свої якості, високий рівень особистісної тривожності, схильність сприймати навколишній світ як загрозливий самооцінці, переважає негативний фон ставлення до себе, присутні високі вимоги до себе, що нерідко призводить до конфлікту між «Я-реальним» і «Я-ідеальним».

За допомогою методики М. Куна «Хто Я?», респондентам необхідно було дати 20 відповідей на одне питання, що відноситься до них самих: «Хто Я?». Не зважаючи на чітку інструкцію, респонденти, не змогли в повній мірі їі виконати. Середня кількість вказаних образів - 8. Тобто у них звужується загальна кількість самовизначень. Також з'являються специфічні негативні конструкти у системі «Я-образів»: «Я-розлучена (ний)», «Я-невдаха», «Яброшенка», «Я-разведенка» та інші.

Надалі, ми вимірювали емоційно-оціночний компонент «Я-образу» за допомогою методики діагностики самооцінки психічних станів Г. Айзенка та методики вимірювання самооцінки ДембоРубінштейн у розлучених. Результати нашого дослідження представлені у таблиці 2.

Таблиця 2. Високі показники за шкалами по методиці самооцінки психічних станів Г. Айзенка.

\begin{tabular}{|c|c|c|c|c|c|}
\hline \multirow{2}{*}{ № } & \multirow{2}{*}{ Група } & \multicolumn{4}{|c|}{ Шкали, \% } \\
\cline { 3 - 6 } & Розлучені & $82,5 \%$ & $62,5 \%$ & $90 \%$ & $70 \%$ \\
\hline 1. & Рривожність & Фрустрація & Ригідність & Агресивність \\
\hline
\end{tabular}


За отриманими даними, можна свідчити, що найбільш виражена ригідність $-90 \%$, що свідчить про відсутність гнучкого мислення та адаптивних можливостей, що виражаються в протипоказані зміни місця роботи, змінення в сім'ї.

Емоційно-оціночний блок «Я-образу» включає не тільки емоційну складову, але й безпосередньо самооцінку, тому наступний підетап спрямований на виявлення іiі рівня. У зв'язку із тим, що після попадання у складну життєву обставину, людина знаходиться у афективному психічному стані і саме це може впливати на рівень самооцінки особистості. Результати методики вимірювання самооцінки Дембо-Рубінштейн представлені у таблиці 3.

Таблиця 3. Рівень самооцінки у розлучених осіб.

\begin{tabular}{|c|l|c|c|c|}
\hline \multirow{2}{*}{ № } & Група досліджуваних & \multicolumn{3}{|c|}{ Показники, у \% } \\
\cline { 3 - 5 } & & Bис. & Сер. & Низ. \\
\hline 1. & Розлучені & 10 & 40 & 50 \\
\hline
\end{tabular}

Отже, найбільш вираженою є саме низька самооцінка (50\%) - схильність до пасивності, навіюванню, надмірної чутливості до критики. На групу розлучених вплинув гендерний фактор, що змінив показники рівня самооцінки, тобто завдяки чоловікам рівень низької самооцінки знизився.

Надалі, ми виявляли особливості зміни поведінкової складової «Я-образу», під впливом розлучення, за методикою діагностики соціально-психологічної адаптації К. Роджерса і Р. Даймонда та методики міжособистісних відношень Т. Лірі (модифікація Л.М. Собчик). Перша методика має 6 полярних шкал, ми виявили найбільш домінуючі показники по шкалам і показали у таблиці 4.

Таблиця 4. Домінуючі показники методики соціально-психологічної адаптації у розлучених

\begin{tabular}{|c|c|c|c|c|c|c|c|c|}
\hline \multirow[t]{2}{*}{ № } & \multirow{2}{*}{$\begin{array}{c}\text { Категорія } \\
\text { досліджуваних }\end{array}$} & \multicolumn{7}{|c|}{ Шкали у \% } \\
\hline & & 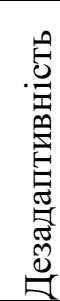 & 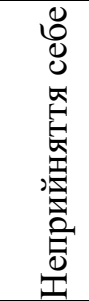 & 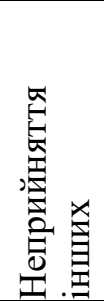 & 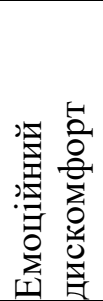 & 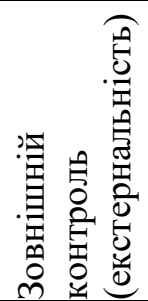 & 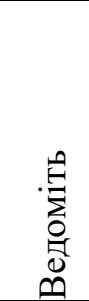 & 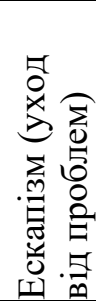 \\
\hline 1. & Розлучення & 75 & 72,5 & 75 & 82,5 & 60 & 72,5 & 67,5 \\
\hline
\end{tabular}

Отже, у розлучених найбільш високі показники за шкалою «емоційний дискомфорт» (82,5\%), «неприйняття інших» (75\%) та «дезадаптивність» $(75 \%)$. За методикою Т. Лірі, ми виявляли різницю між «Я-актуальним» та «Я-ідеальним» і було виявлено, що розлученні $(75 \%)$, мають велику розбіжність між «Я-актуальним» та «Я-ідеальним» що свідчить про те, що людина незадоволена собою, не приймає себе, свого «Я-образу» та образу ситуації. Також за методикою Т. Лірі, ми виявляли типи відношення до оточуючих за всіма групами респондентів, де 0-7 низький показник вираженості, 8-12 - середній показник та 13-16 високий показник шкал. Дані відображені у діаграмі 1.

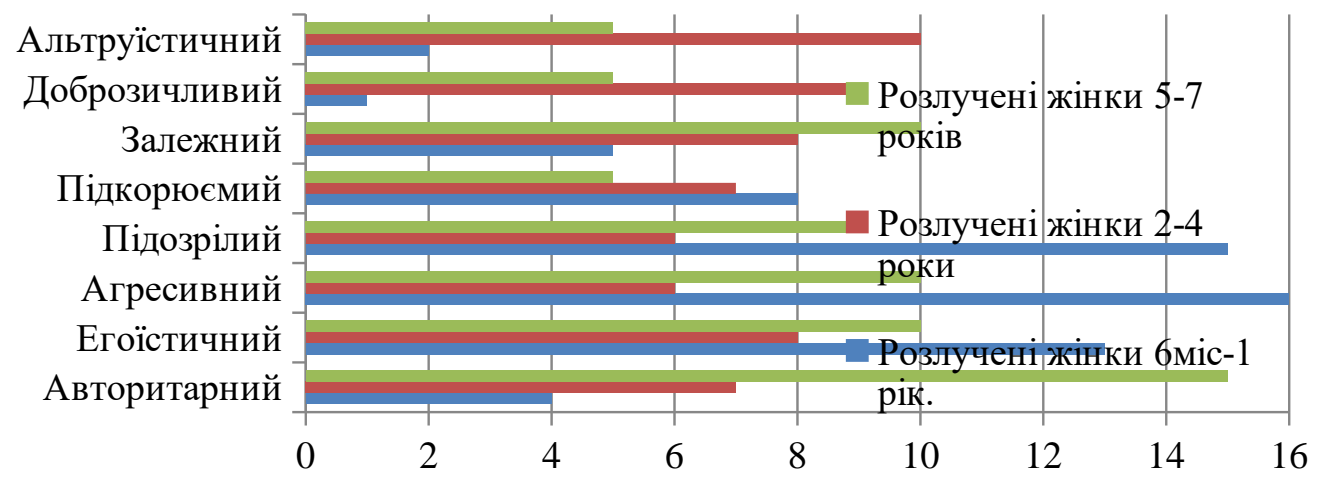

Рис.1. Типи відночення до оточуючих у розлучених осіб.

Можна припустити, що саме у перший період переживання розлучення (6 міс-1 рік) у осіб домінуючими типами відношення до оточуючих - це агресивний, жорсткий і ворожий до інших, різкий, агресивність може доходити до асоціальної поведінки та підозрілий тип, що свідчить про відчуженість по відношенню до ворожого і злобного світу, образливий, схильний до сумніву в усьому, злопам'ятний, постійно на всіх скаржиться, всім незадоволений (шизоїдний тип характеру). 2-4 роки у розлученні за отриманими даними не мають відхилень від норми та 
переважають усі типи відношення до оточуючих у приблизно рівних частинах, що свідчить про пластичність у поведінці та вміння конструктивно вистроювати стосунки. Досліджувані 3 періодом розлучення 5-7 років, мають домінуючий тип відношення до оточуючих - це авторитарний, диктаторський, владний, деспотичний характер, тип сильної особистості, яка лідирує у всіх видах групової діяльності, всіх наставляє, повчає, у всьому прагне покладатися на свою думку, не вміє приймати поради інших.

Таким чином, особливості переживання розлучення, як складної життєвої обставини змінює більш за все когнітивний компонент: звужується кількість образів особистості та 3'являються специфічні деструктивні образи. Такі образи як, «Я-разведена», свідчить про зміну «Я-соціального» та образу «Я-жінка/чоловік». Чітко простежується негативне самоставлення до себе та оточуючих. Також $є$ певні гендерні відмінності у показниках зміни «Я-образу», тобто для чоловіків розлучення не $\epsilon$ настільки руйнівною обставиною, ніж для жінок. Це може бути пов'язане із тим, що в родинах, тільки чоловік виконував фінансову функцію, що загалом змінює образ життя жінки, що в свою чергу вплинув на зникнення образу - «Я-жінка».

Другий eman присвячений виміру особливостей змін структурних компонентів «Яобразу» у осіб з тимчасовою інвалідністю (9-12 міс. реабілітації, перелом руки або ноги) Результати показників за даним етапом представлені у таблиці 5.

Таблиця 5. Результати дослідження за тестом - опитувальником самовідношення В.В. Століна, С.Р. Пантілєєва у \%.

\begin{tabular}{|c|c|c|c|c|c|c|c|c|c|c|}
\hline \multirow[b]{2}{*}{$\begin{array}{c}\text { №, групи } \\
\text { досліджуваних }\end{array}$} & \multirow[b]{2}{*}{ 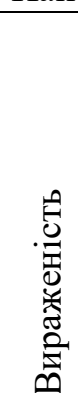 } & \multicolumn{9}{|c|}{ Показники у \% } \\
\hline & & 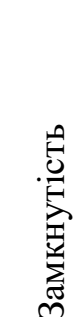 & 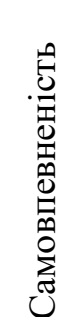 & 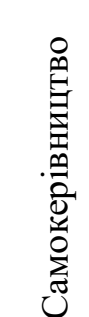 & 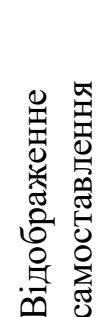 & 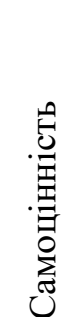 & 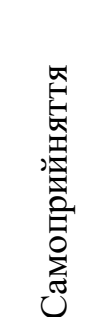 & 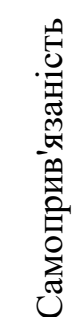 & 覞氪 & 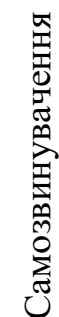 \\
\hline \multirow{3}{*}{$\begin{array}{l}\text { 2. Тимчасова } \\
\text { інвалідність } \\
\text { (9-12 міс. } \\
\text { реабілітація) }\end{array}$} & вис. & 91,5 & 14 & 3 & 0 & 0 & 11,4 & 80 & 88,6 & 17 \\
\hline & cep. & 5,7 & 72 & 68,5 & 25,7 & 77 & 8,6 & 11,4 & 8,6 & 53 \\
\hline & низ. & 2,8 & 14 & 28,5 & 74,3 & 23 & 80 & 8,6 & 2,8 & 30 \\
\hline
\end{tabular}

У даної групи досліджуваних, високі показники за шкалами: «замкнутість» (91,5\%), «самоприв'язаності» $(80 \%)$ та «внутрішній конфлікт» $(88,6 \%)$. За низькими показниками: «самоприйняття» $(80 \%)$ та «відображене самоставлення» $(74,3 \%)$. Усі інші шкали мають середній рівень вираженості показників. що свідчить про виражену захисну поведінку особистості. Можна побачити певні схожість за показниками з розлученими особами.

За допомогою методики М. Куна «Хто Я?», респондентам необхідно було дати 20 відповідей на одне питання, що відноситься до них самих: «Хто Я?». Не зважаючи на чітку інструкцію, респонденти, не змогли в повній мірі ії виконати. Середня кількість вказаних образів - 7. З'являються специфічні негативні конструкти у системі «Я-образів»: «Я-інвалід», «Я-безпомічна(ний)», «Я-обуза», «Я-жалюгідна (ний)» та інші.

Надалі, ми вимірювали емоційно-оціночний компонент «Я-образу», результати нашого дослідження представлені у таблиці 6.

Таблиця 6. Високі показники за шкалами по методиці самооцінки психічних станів Г. Айзенка.

\begin{tabular}{|c|c|c|c|c|c|}
\hline \multirow{2}{*}{ № } & Група & \multicolumn{4}{|c|}{ Шкали, \% } \\
\cline { 3 - 6 } & Тривожність & Фрустрація & Ригідність & Агресивність \\
\hline 1. & $\begin{array}{c}\text { Тимчасова інвалідність (9-12 } \\
\text { міс. реабілітації) }\end{array}$ & $86 \%$ & $71 \%$ & $86 \%$ & $83 \%$ \\
\hline
\end{tabular}

Отже, можна свідчити, що найбільш виражена ригідність (86\%) та тривожність (86\%), що свідчить про відсутність гнучкого мислення та адаптивних можливостей, що виражаються в протипоказані зміни місця роботи, змінення в сім'ї. У осіб з тимчасовою інвалідністю (74\%) переважає низька самооцінка.

У осіб з тимчасовою інвалідністю (перелом руки або ноги, 9-12 міс. реабілітації) виражена «дезадаптивність» - 88\%, «неприйняття інших» - 83\%, що говорить про відсутність 
потреби особистості в спілкуванні, взаємодії, спільної діяльності з іншими та «емоційний дискомфорт» - 83\%. Також мають ще більш велику розбіжність між «Я-актуальним» та «Яідеальним» що свідчить про те, що людина незадоволена собою, не приймає себе, свого «Яобразу» та образу ситуації.

Також на цьому етапі за методикою Т. Лірі, ми виявляли типи відношення до оточуючих, де 0-7 низький показник вираженості, 8-12 - середній показник та 13-16 високий показник шкал. Дані відображені у діаграмі 2.

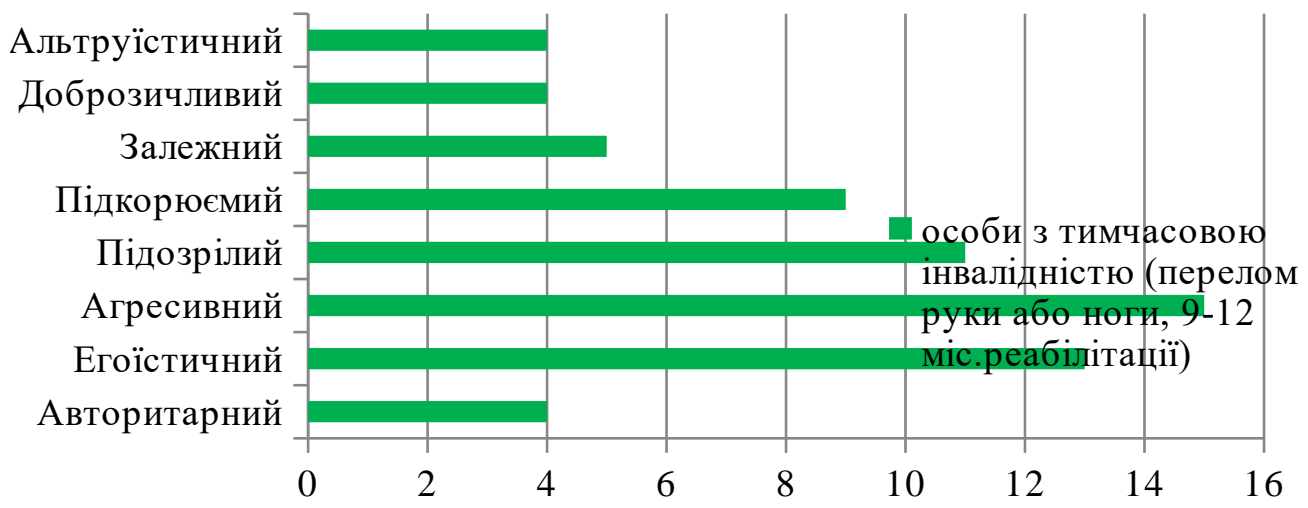

Рис.2. Типи відношення до оточуючих у осіб з тимчасовю інвалідністю (перелом руки або ноги, 9-12 міс. реабілітаuіiі)

Можна побачити за діаграмою, що у осіб з тимчасовою інвалідністю домінуючими типами відношення до оточуючих - це агресивний, жорсткий і ворожий до інших, різкий, агресивність може доходити до асоціальної поведінки та підозрілий тип, що свідчить про відчуженість по відношенню до ворожого i злобного світу, образливий, схильний до сумніву в усьому, злопам'ятний, постійно на всіх скаржиться, всім незадоволений (шизоїдний тип характеру). Також егоїстичний тип, що свідчить про егоїстичні риси, орієнтація на себе, схильність до суперництва.

Таким чином, тимчасова інвалідність (перелом руки або ноги, 9-12 міс. реабілітації) трансформує «Я-образ» та його компоненти, найбільш потужно. Образ «Я-інвалід» та «Яобуза», «Я-каліка» свідчить про зміну «Я-тілесного» в першу чергу, «Я-реального» та «Яідеального». За усіма показниками за всіма даними, ця категорія має самі висові показники. Зміни є у когнітивному компоненті: відсутність класичних образів, звуження представлення про Я, негативне самоставлення. У емоційно-оцінному компоненті простежується низька самооцінка майже у кожного досліджуваного та емоційний фон за усіма шкалами має високі показники. Поведінкова складова виражається у негативному ставленні до інших та деструктивними стратегіями поведінки з оточуючими.

Ha Tpemboмy emani ми визначали зміни, які виникають у структурних компонентах «Яобразу» у безробітних (звільнених). Результати показників за даним етапом представлені у таблиці 7.

Таблиця 7. Результати дослідження за тестом - опитувальником самовідношення В.В. Століна, С.Р. Пантілєєва у \%.

\begin{tabular}{|c|c|c|c|c|c|c|c|c|c|c|}
\hline \multirow[b]{2}{*}{$\begin{array}{c}\text { №, групи } \\
\text { досліджуваних }\end{array}$} & \multirow[b]{2}{*}{ 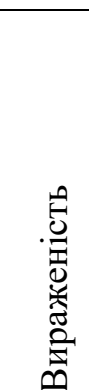 } & \multicolumn{9}{|c|}{ Показники у \% } \\
\hline & & 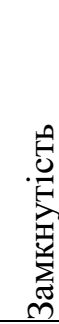 & 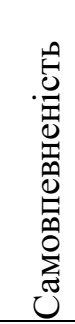 & 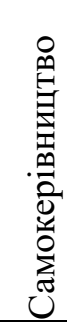 & 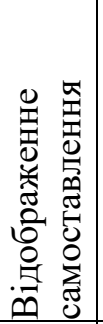 & 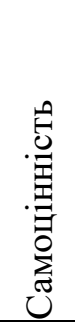 & 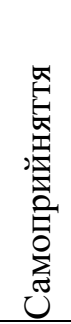 & 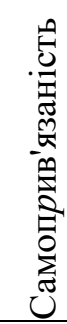 & 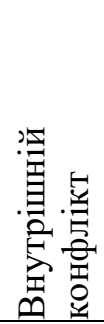 & 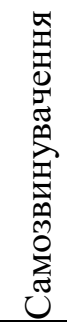 \\
\hline \multirow{3}{*}{$\begin{array}{l}\text { 1. Безробітні } \\
\text { (звільнені) }\end{array}$} & вис. & 20 & 13 & 33 & 33 & 33 & 20 & 73 & 80 & 17 \\
\hline & cep. & 60 & 0 & 54 & 57 & 50 & 3 & 13 & 7 & 0 \\
\hline & низ. & 20 & 77 & 13 & 10 & 17 & 77 & 14 & 13 & 83 \\
\hline
\end{tabular}


У досліджуваній групі безробітних (звільнених) високий ступінь вираженості за шкалами «самоприв'язаності» (73\%), що відображають високу ригідність «Я», прагнення зберегти в незмінному вигляді свої якості, вимоги до себе, високий рівень особистісної тривожності, схильність сприймати навколишній світ як загрозливий самооцінці; «внутрішній конфлікт» (80\%), що відповідає особам, у яких переважає негативний фон ставлення до себе, вони знаходяться в стані постійного контролю над своїм «Я», прагнуть до глибокої оцінки всього, що відбувається в ії внутрішньому світі, відрізняється високими вимогами до себе. За низькими показниками, виражені такі шкали, як «самовпевненість» $(77 \%)$, що свідчить про неповагу до себе, пов'язану 3 невпевненістю в своїх можливостях, відсутня довіра своїм рішенням, можливі уникнення контактів 3 людьми, глибоке занурення у власні проблеми, внутрішня напруженість; «самоприйняття» $(77 \%)$ що вказує на загальний негативний фон сприйняття себе, на схильність сприймати себе надто критично; «самозвинувачення» (83\%) виявляють тенденцію до заперечення власної провини в конфліктних ситуаціях, захист власного «Я» здійснюється шляхом звинувачення переважно інших, перенесенням відповідальності на оточуючих за усунення бар'єрів на шляху до досягнення мети.

За допомогою методики М. Куна «Хто Я?», не зважаючи на чітку інструкцію, респонденти, не змогли в повній мірі ії виконати. Середня кількість вказаних образів - 15 . Також з'являються специфічні негативні конструкти у системі «Я-образів»: «Ябезробітна(ний)», «Я-звільнена(ний)», «Я-поганий співробітник», «Я-нікчема» та інші.

Надалі, ми вимірювали емоційно-оціночний компонент «Я-образу». За методикою Г. Айзенка, жінки та чоловіки, які вимушено звільнені мають високий рівень тривожності (93\%), низьку самооцінку, бажання уникнення невдач, сильно виражена ригідність (77\%), що свідчить про протипоказання щодо зміни місця роботи, змінення у сім'ї, та високий рівень агресивності (73\%), нестриманості у взаємодії з людьми.

У безробітних (звільнених) на 90\% виражено «зовнішній контроль-екстернальність», тобто домінує схильність приписувати причини того, що відбувається зовнішніми факторами (навколишньому середовищу, долі або випадку).

Також на цьому етапі за методикою Т. Лірі, ми виявляли типи відношення до оточуючих у безробітних (звільнених), де 0-7 низький показник вираженості, 8-12 - середній показник та 13-16 високий показник шкал. Дані відображені у діаграмі 3.

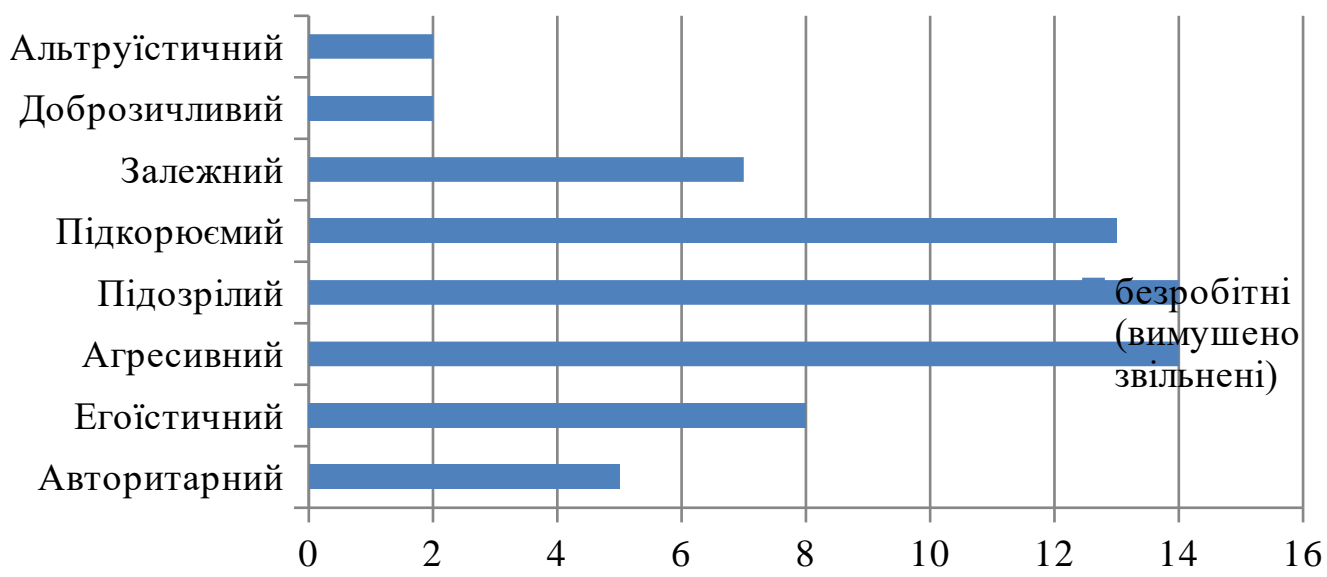

Рис.3 Типи відношення до оточуючих у безробітних (звільнених)

у безробітних домінуючими типами відношення до оточуючих - це агресивний, жорсткий і ворожий до інших, різкий та підозрілий тип, що свідчить про відчуженість по відношенню до ворожого і злобного світу, образливий, схильний до сумніву в усьому, злопам'ятний, постійно на всіх скаржиться, всім незадоволений (шизоїдний тип характеру). Також підкорюємий тип, що свідчить покірність, схильний до самоприниження, слабовільний, схильний поступатися всім і в усьому, завжди ставить себе на останнє місце і засуджує себе, приписує собі провину, пасивний, прагне знайти опору в кому-небудь більш сильному.

Таким чином, безробітні (звільнені) мають більш наповнений когнітивний компонент та кількість вказаних образів більше середнього, але також присутні певні конструктивні образи, які вказують на специфічну трансформацію «Я-образу», наприклад «Я-поганий співробітник» 
свідчить про певний психологічний бар'єр у майбутньому, як становлення себе компетентним професіоналом. Змінюється «Я-соціальне» та «Я-ідеальне».

Ha Четвертому emani ми визначали особливості трансформації компонентів «Яобразу», в ситуації переселення у зв'язку із бойовими діями. Результати показників за даним етапом представлені у таблиці 8.

Таблиця 8. Результати дослідження за тестом - опитувальником самовідношення В.В. Століна, С.Р. Пантілєєва у \%.

\begin{tabular}{|c|c|c|c|c|c|c|c|c|c|c|}
\hline \multirow[b]{2}{*}{$\begin{array}{c}\text { №, групи } \\
\text { досліджуваних }\end{array}$} & \multirow[b]{2}{*}{ 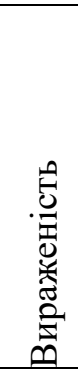 } & \multicolumn{9}{|c|}{ Показники у \% } \\
\hline & & 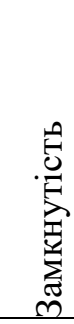 & 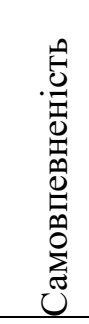 & 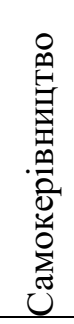 & 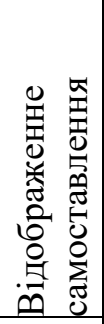 & 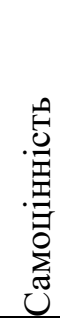 & 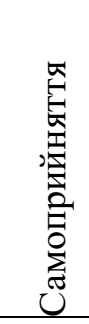 & 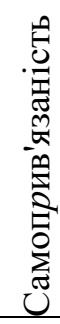 & 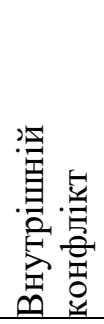 & 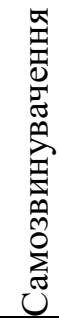 \\
\hline \multirow{3}{*}{ 1. Переселенці } & вис. & 12,5 & 2,5 & 25 & 25 & 30 & 22,5 & 75 & 80 & 20 \\
\hline & cep. & 62,5 & 27,5 & 65 & 57,5 & 50 & 10 & 0 & 12,5 & 0 \\
\hline & низ. & 25 & 70 & 10 & 17,5 & 20 & 77,5 & 25 & 7,5 & 80 \\
\hline
\end{tabular}

У переселенців за високими показниками виражені такі шкали, як «самоприв'язаність» (75\%) та «внутрішній конфлікт» (80\%). За низькими показниками у цих групах досліджуваних виражені такі шкали: «самовпевненість» $(77,5 \%)$ та «самозвинувачення» $(80 \%)$.

За допомогою методики М. Куна «Хто Я?», не зважаючи на чітку інструкцію, респонденти, не змогли в повній мірі ії виконати. Середня кількість вказаних образів - 15 . Також з'являються специфічні негативні конструкти у системі «Я-образів»: «Я-нікчема», «Япереселенка (ець)», «Я-брошена», «Я-утриманка», «Я-паразит» та інші.

При досліджуванні емоційно-оцінного компонента «Я-образу», ми виявили, що переселенці мають високий рівень тривожності (75\%), а ригідність, фрустрованість та агресивність мають середні показники.

У досліджуваної групи, найбільш порушений уход від проблеми $(77,5 \%)$, тобто уникнення проблемних ситуацій. Також дезадаптивність $(72,5 \%)$ - визначає незрілість особистості, невротичні відхилення, дисгармонії в сфері прийняття рішення, які є результатом постійних неуспішних спроб індивіда реалізувати мету або наявності двох і більше рівнозначних цілей. Та високі показники за шкалою «зовнішній контроль» (70\%) свідчать про схильність приписувати причини того, що відбувається зовнішніми факторами (навколишньому середовищу, долі або випадку). Також за методикою Т. Лірі, ми виявляли типи відношення до оточуючих у переселенців, де 0-7 низький показник вираженості, 8-12 середній показник та 13-16 високий показник шкал. Дані відображені у діаграмі 4.

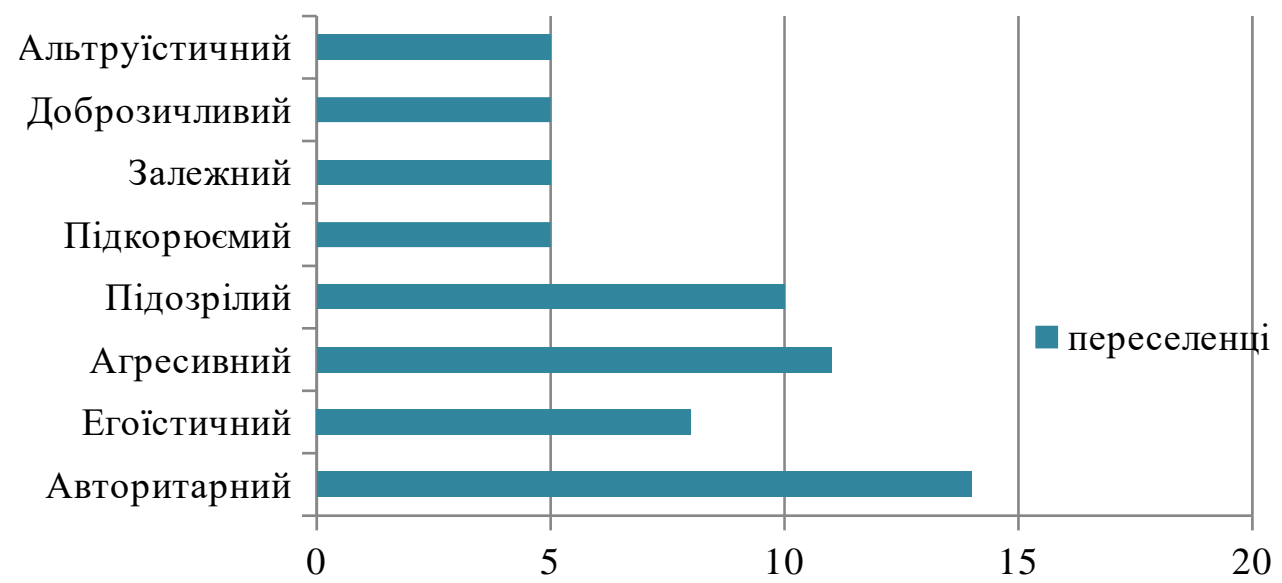

Рис. 4 Типи відношення до оточуючих у переселенщів. 
У переселенців домінуючими типами відношення до оточуючих - це агресивний, жорсткий і ворожий до інших, різкий, агресивність може доходити до асоціальної поведінки та підозрілий тип, що свідчить про відчуженість по відношенню до ворожого і злобного світу, образливий, схильний до сумніву в усьому, злопам'ятний, постійно на всіх скаржиться, всім незадоволений (шизоїдний тип характеру). Також авторитарний, диктаторський, владний, деспотичний характер, тип сильної особистості, яка лідирує у всіх видах групової діяльності. Всіх наставляє, повчає, у всьому прагне покладатися на свою думку, не вміє приймати поради інших.

Отже, переселенці 3 усіх груп досліджуваних мають в середньому більш стабільні результати. Найбільш значущі показники за шкалою «дезадаптивність». Та особливістю зміни під впливом цієї складної життєвої обставини $є$ те, що за показниками найбільше виражено негативне ставлення до оточуючих, бажання перекласти відповідальність на зовнішні чинники або людей.

Висновки. Таким чином, результати нашого дослідження за усіма етапи дослідження свідчать про те, що в залежності від виду складної життєвої обставини, що впливає на життєдіяльність особистості, по різному змінює компоненти «Я-образу». Загальним є те, що емоційно-оцінний компонент у всіх груп досліджуваних виражається у дуже високих показникам негативного самопочуття та низькій самооцінці. Також з'являються різні специфічні образи в залежності від обставини, що змінюють «Я-тілесне», «Я-соціальне», «Яідеальне», «Я-майбутнє» та інші.

\section{ЛIТЕРАТУРА}

1. Гуменюк О. Структурно-функціональне взаємодоповнення складових «Я-концепції» людини / О. Гуменюк // Соціальна психологія. - 2005. - № 5. - С. 68.

2. Кірєєва У. Психологічний аналіз «Я-концепції» у контексті самосвідомості / У. Кірєєва // Психологія і суспільство. - 2010. - № 1. - С. 122.

3. Особистість як суб’єкт подолання кризових ситуацій: психологічна теорія і практика: монографія / за ред. С. Д. Максименка, С.Б. Кузікової, В. Л. Зливкова. / Швалб Ю.М. Психологічна структура складних життєвих обставин - Суми : Вид-во СумДПУ імені А. С. Макаренка, 2017. - С. 19-39.

4. Постанова кабінету міністрів України від 1 серпня 2013 р. № 573, Київ «про затвердження загального положення про центр соціальних служб для сім'ї, дітей та молоді» \{із змінами, внесеними згідно з постановами км № 495 від 17.07.2015, № 528 від 19.07.2017, № 43 від 23.01.2019\} 